\title{
NEUROMUSCULAR BLOCK BY CIRCULATING D-TUBOCURARINE RESIDUE FOLLOWING UPTAKE AND DISTRIBUTION
}

\author{
Elaine Yang and Chingmuh Lee
}

FolLOWING THE INTRAVENOUS ADMINISTRATION of d-tubocurarine, the concentration of the drug circulating in the central compartment falls rapidly because of distribution and uptake by the tissue. ${ }^{1-4}$ If the amount of drug administered is below a certain limit, the circulating residue remaining in the blood after uptake and distribution could rapidly decrease below the threshold for block. A low circulating residue of the drug is of clinical importance from the viewpoint of "recurarization", particularly in patients with decreased ability to metabolize or excrete the drug.

This study concentrates on the uptake and distribution of d-tubocurarine immediately after its intravenous injection. The amount of d-tubocurarine which would not leave a significant circulating residue in the blood five minutes after its intravenous injection and the neuromuscular effects of the circulating residue after injection of larger doses were determined.

\section{Methons}

Twenty-nine observations were made in six healthy cats of both sexes, weighing between 1.7 and $4.7 \mathrm{~kg}$ ( $3.10 \pm 1.1$; mean \pm S.D. $)$. Anaesthesia was induced with an intraperitoneal injection of chloralose $60 \mathrm{mg} / \mathrm{kg}$ and pentobarbitone $20 \mathrm{mg} / \mathrm{kg}$. A tracheostomy was performed and the cats were ventilated with air by a Palmer pump at approximately $320 \mathrm{mI} / \mathrm{kg} / \mathrm{min}$. The blood gases were checked at intervals and found to be within normal limits for cats ( $\mathrm{Po}_{2}$ 94-110 torr (12.4-17.6 kPa), $\mathrm{PCO}_{2} 26-30$ torr $(3.4-3.9 \mathrm{kPa}) \mathrm{pH} 3.36-3.39$. An intravenous line for fluid and drug administration was secured, and one carotid artery was cannulated for continuous monitoring of the blood pressure. Hydration was maintained by lactated Ringer's solution with 5 per cent glucose at approximately $5 \mathrm{ml} / \mathrm{kg} /$ hour. The core temperature was maintained at approximately $36^{\circ} \mathrm{C}$.

The femoral arteries were exposed bilaterally. Both sciatic nerves were exposed, crushed or severed proximally, and stimulated distally. The tendinous sheath surrounding the tibialis anterior tendon was incised. The muscle was detached from its insertion and attached to a Grass FT 10C force displacement transducer. Both hind legs were immobilized at the knee and the ankle on a heavy metal frame. The sciatic nerves were stimulated every 10 seconds with 0.2 msec square pulses of supramaximal voltage. The preload necessary for maximum twitch output was applied to the muscle. This approximated $50 \mathrm{gm}$ in most cats.

Elaine Yang, M.D. and Chingmuh Lee, M.D., Department of Anesthesiology, UCLA School of Medicine, Los Angeles, CA. 90024.

Communications to: Chingmuh Lee, M.D., Associate Professor, Department of Anesthesiology, UCLA School of Medicine, Los Angeles, CA. 90024. 
After obtaining a steady twitch response, a tetanic stimulus of $50 \mathrm{~Hz}$ was applied for five seconds. The preparation was then allowed to stabilize. The preload was adjusted as needed. Next, both femoral arteries were occluded for five minutes to see the effects of ischaemia on twitch height, if any. Arterial occlusion of five minutes duration was found not to affect the twitch height. In similar studies, Katz has previously observed that arterial occlusion for up to 20 minutes does not affect the twitch height (unpublished observation). Following this, the arteries were unclamped and the preparation was rested before the experiment began.

The femoral artery on one side, the test side, was then occluded, and an intravenous injection of $d$-tubocurarine was made immediately. The neuromuscular blocking effects were first observed on the unoccluded reference side. The absence of a train-of-four fade on the test side assured us of an effective circulatory occlusion. Five minutes after the injection of d-tubocurarine, perfusion was restored to the test side. The effects of the residual plasma d-tubocurarine were thereby observed.

At least 30 minutes elapsed after the twitch, the train-of-four, and the tetanus returned to normal on both sides before the next dose of d-tubocurarine was given and the observations were repeated. The time interval between injections varied between 1 and 3 hours. In a few instances, collateral circulation allowed d-tubocurarine to cause a neuromuscular block on the "unperfused" test side. When this occurred, the study was repeated with the test side and the reference side interchanged. If we again found evidence of collateral circulation, the occlusion site was moved further up to the common iliac artery. If complete occlusion was still not obtainable with this manoeuvre, the experiment was abandoned.

\section{RESULTS}

With one femoral artery occluded, a dose of d-tubocurarine $0.17( \pm 0.02$, S.E.) $\mathrm{mg} / \mathrm{kg}$, ED 50, blocked the neuromuscular transmission as measured in the unoccluded reference leg by 50 per cent. The corresponding "ED 95 " was 0.25 ( \pm 0.03, S.E.) $\mathrm{mg} / \mathrm{kg}$.

Five minutes after an intravenous injection of the ED 50 dose of d-tubocurarine, the residual plasma curare produced no block of the twitch, nor a change in the train-of-four ratio on the previously occluded test side (Figure 1). After an ED 95 dose of d-tubocurarine, the plasma residue in five minutes was sufficient to produce a 15 per cent to 38 per cent block on the previously occluded test side (Figure 2). Thereafter increasing the dose produced an increasing residual block on the previously occluded test side (Figure 3 ). Approximately $2.5 \times$ ED 50 was required to leave a circulating residue sufficient for a 50 per cent block. A dose of 5 to 6 times the ED 50 was required to produce a plasma tubocurarine residue in five minutes for a total block of the previously occluded test side (Table I).

\section{Discussion}

Following intravenous injection, the circulating d-tubocurarine diminishes rapidly. ${ }^{1-4}$ We made observations on the circulating residue five minutes after 

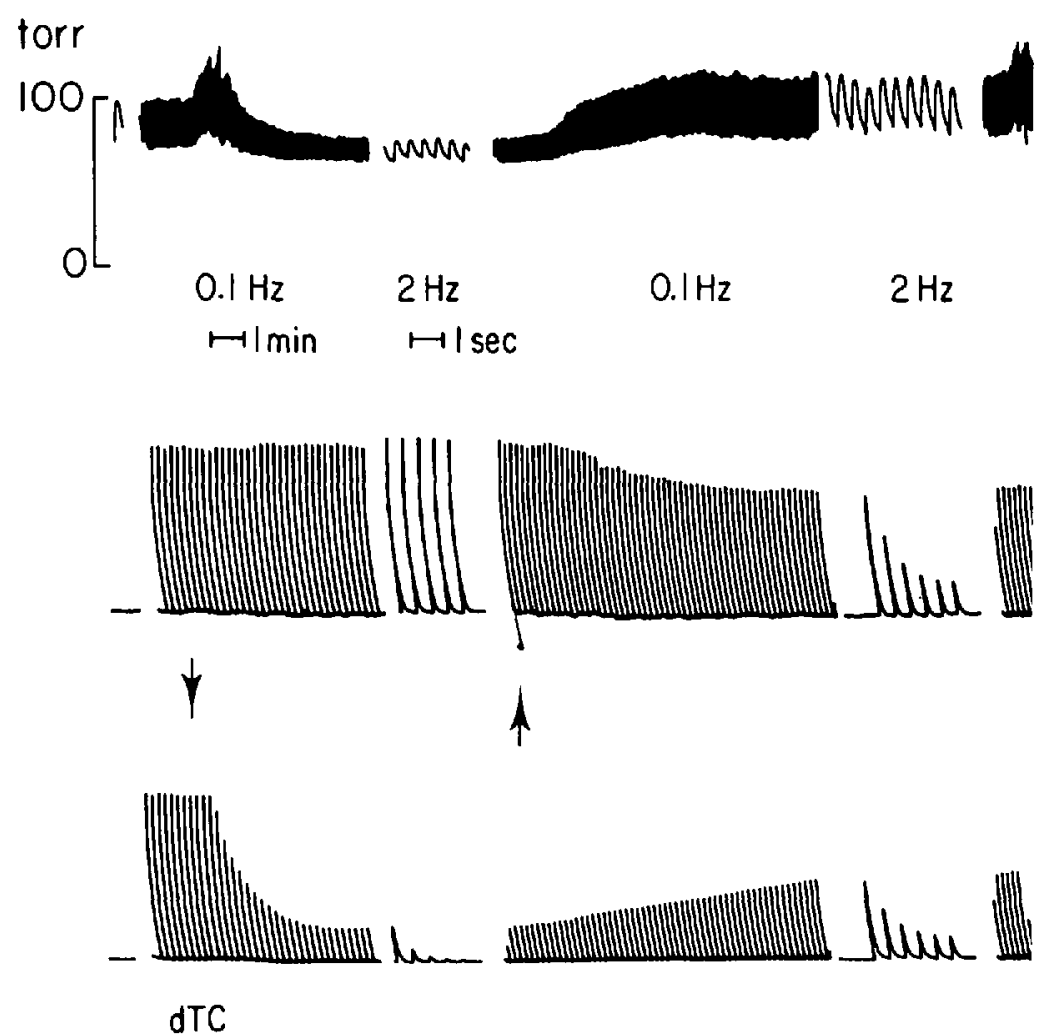

Figure 1. Neuromuscular blocking effects of d-tubocurarine residue in the cat. Upper panel: arterial blood pressure. Middle panel: neurally elicited left tibialis anterior muscle twitch, the test preparation. Lower panel: identical preparation on right leg, the reference preparation. The first arrow indicates when d-tubocurarine $(0.175 \mathrm{mg} / \mathrm{kg})$ was injected intravenously, with the circulation to the left leg interrupted. The second arrow indicates when the residual d-tubocurarine was allowed to circulate to the left side, five minutes later. A train-of-four at $2 \mathrm{~Hz}$ was recorded on both sides at a faster paper speed, five minutes after injection of $\mathrm{dTC}$, and at maximum effect of d-tubocurarine residual on the test side.

injection because approximately five minutes are required for the onset of neuromuscular block. The major portion of uptake must have been just completed when the neuromuscular blocking effect has stabilized.

Our results indicate that five minutes after its intravenous injection, an ED 50 dose of d-tubocurarine will leave so little residue as to produce no block in a previously unexposed neuromuscular junction. Five minutes after an intravenous injection of $2.5 \times \mathrm{ED} 50$ dose of d-tubocurarine, the circulating plasma residue produces a 50 per cent block (i.e. $1 \times$ ED 50 ). The plasma residue in five minutes is, therefore, approximately 40 per cent of the initial concentration.

It is possible that the circulating d-tubocurarine residue fails to produce a block in a previously unexposed neuromuscular junction because of reserves in the neuromuscular transmission, a receptor occlusion less than 70 per cent having no effect on the twitch response. In other words, the reference side may have a 90 per cent receptor occlusion and a 50 per cent block, for example, while the test side may have a 70 per cent receptor occlusion and no block. ${ }^{5,6}$ It is also possible that the 


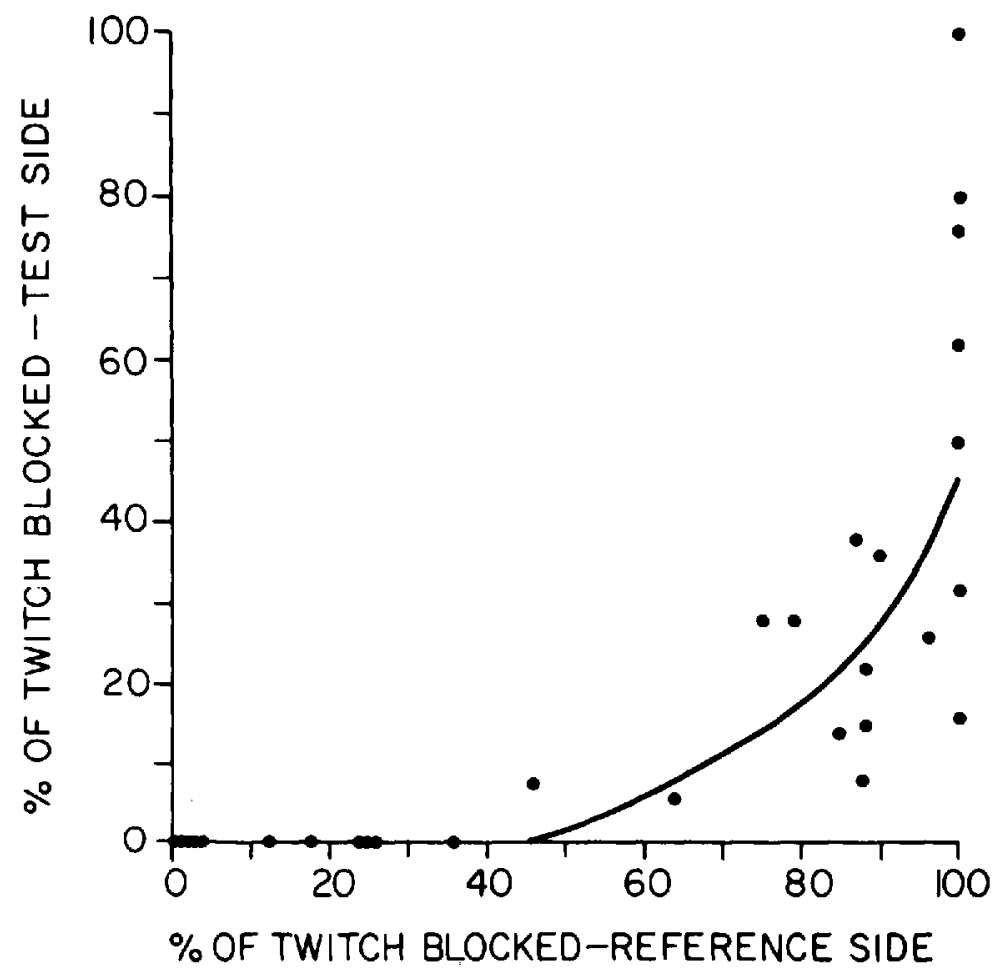

Figune 2. A comparison of the neuromuscular block on the reference versus the test side. The reference side received the actual dosage of d-tubocurarine while the test side was blocked by the residual d-tubocurarine remaining in the circulation five minutes after intravenous injection. The curve was visually fit.

concentration of $d$-tubocurarine in the central compartment actually falls to such a low level that there is not enough circulating d-tubocurarine for the previously unexposed neuromuscular junction to achieve a significant (i.e. near 70 per cent) receptor occupation. In other words, the concentration gradient of the drug between the site of action and serum is great.

The latter case is supported by data previously reported by Matteo, Spector and Horowitz, ${ }^{7}$ and Gibaldi, Levy and Hayton. ${ }^{2}$ According to Matteo, et al., a 50 per cent neuromuscular block in man corresponds to a serum d-tubocurarine concentration of $0.45 \mu \mathrm{g} / \mathrm{ml}$. In a $70 \mathrm{~kg}$ man, this is equivalent to a total of $1.3 \mathrm{mg}$ of d-tubocurarine in the serum ( 4 per cent body weight), which is a small fraction of an ED 50 dose. This means that only a small fraction of the drug remains in the blood, despite existence of a 50 per cent neuromuscular block. Our results further indicate that a low serum concentration and a high concentration gradient of d-tubocurarine from the neuromuscular junction to serum are established inmediately after intravenous injection of the drug. Therefore, although the serum concentration of d-tubocurarine correlates with the block, the circulating d-tubocurarine is not sufficient to cause the corresponding block. ${ }^{7-10}$

The rapid decrease of the circulating d-tubocurarine concentration following its intravenous injection can not be plausibly attributed to metabolism and excre- 


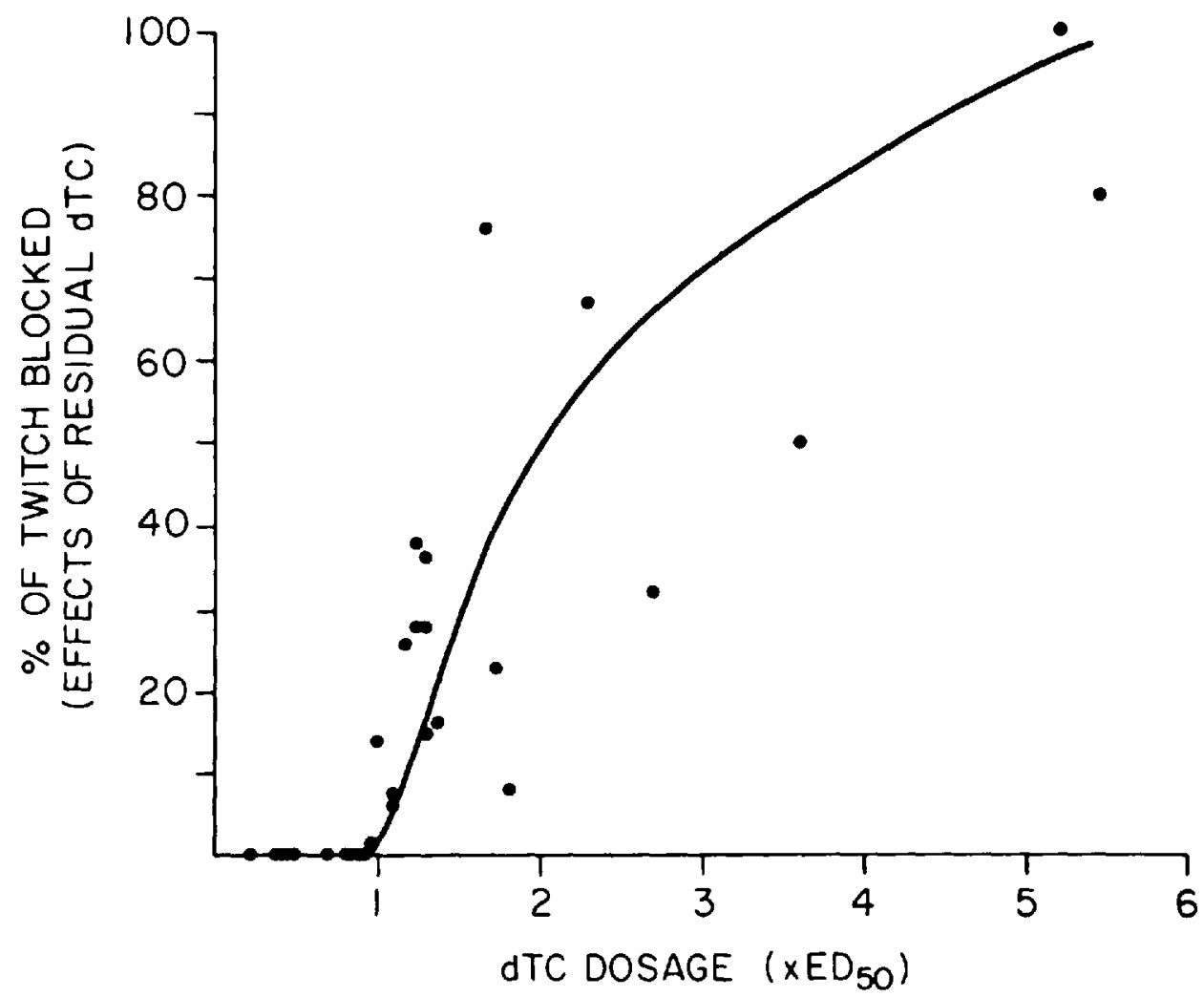

Figure 3. Neuromuscular blocking effects of residual d-tubocurarine. The dose of d-tubocurarine given is expressed in terms of the specific ED50 which was determined for each cat. The curve was visually fit.

TABLE I

Neuromuscular Effect of Residual D-Tubocurarine

\begin{tabular}{lc}
\hline & $\begin{array}{c}\text { Circulating residual d-tubocurarine } \\
\text { effect in five minutes }\end{array}$ \\
\hline $1 \times$ ED $50(50 \%$ block $)$ & No effect \\
$2.5 \times$ ED 50 & $50 \%$ block \\
$5-6 \times$ ED 50 & $100 \%$ block \\
\hline
\end{tabular}

tion of the drug. If it depends primarily on distribution, protein-binding, and tissue uptake, it should occur nearly normally even in patients with renal failure ${ }^{11,12}$ or patients with impaired metabolism and excretion. There seems to be a margin of safety sufficient for safe use of nondepolarizing muscle relaxants in these patients. Despite prolonged action, successful reversal is usually possible ${ }^{13-15}$ and re-curarization rarely occurs if the dosage employed is not high ${ }^{5}$ and if gallamine is not used. ${ }^{1 / 4}$

\section{SumMariy}

Serum concentration of d-tubocurarine decreases rapidly after intravenous injection because of uptake and distribution. The circulating residue of an ED 50 dose 
of d-tubocurarine five minutes after injection will produce no block in a previously unexposed neuromuscular junction. To produce a 50 per cent block with the circulating d-tubocurarine residue in a previously unexposed neuromuscular junction requires an initial injection of $2.5 \times \mathrm{ED} 50$ dose. Five minutes after a dose 5 to 6 times the $\mathrm{ED} 50$, the plasma d-tubocurarine residue is sufficient to produce a total block.

\section{RÉSUMÉ}

La concentration sérique de d-Tubocurarine tombe rapidement après son injection intraveineuse, ceci par redistribution et absorption tissulaire. La quantité résiduelle circulante peut être insuffisante pour produire un effet bloquant si la dose initiale injectée est inférieure à une dose-seuil.

Ce travail, effectué chez le chat, avait pour objectif de trouver la dose de d-Tubocurarine ne laissant pas de résidu circulant en quantité significative, cinq minutes après son administration, et, en second lieu, d'évaluer l'activité des doses résiduelles en circulation après des doses importantes.

Pour quantifier le bloc produit, l'on a utilisé une préparation sciatique-jambier antérieur bilatérale, la circulation étant bloquée dans l'un des côtés pour permettre à ce côté de servir de contrôle pendant l'étude des effets de la d-Tubocurarine de l'autre côté.

Le résidu d'une dose initiale suffisante pour bloquer la conduction neuromusculaire à 50 pour cent (ED 50) n’a pas d'effet bloquant cinq minutes après l'injection.

La dose résiduelle en circulation, lorsque 2.5 fois la dose ED 50 est utilisé, bloque la conduction neuro-musculaire à 50 pour cent. Enfin, le résidu circulant d'une dose de cinq à six fois ED 50, produit un bloc de 100 pour cent.

\section{REFERENCES}

1. Wylie, W.D. \& Churchill-Davidson, H.C. A practice of anaesthesia, 3rd ed. Chicago: Yearbook Medical Publishers, Inc., p. 878 (1972).

2. Gibaldi, M., Levy, G., \& HaYton, W. Kinetics of the elimination and neuromuscular blocking effects of d-tubocurarine in man. Anesthesiology 36:213 (1972).

3. Cohen, E.N., Corbascio, A., \& Fleischli, G. The distribution and fate of d-tubocurarine. J: Pharm. Exp. Ther. 147: 120 (1964).

4. KALOW, W. The distribution, destruction and elimination of muscle relaxants. Anesthesiology 20:505 (1959).

5. LeE, C., Barnes, A., МoK, M., \& KATz, R.L. Absence of "re-curarization" in patients with demonstrated prolonged neuromuscular block. Brit. J. Anaesth. 49: 485 (1977).

6. WAUn, B.E. \& WAUD, D.R. The margin of safety of neuromuscular transmission in the muscle of the diaphragm. Anesthesiology 37: 417 (1972).

7. Matreo, R.S., Spector, S., \& Hohowitz, P.E. Relation of serum d-tubocurarine concentration to neuromuscular blockade in man. Anesthesiology 41:440 (1974).

8. Feldman, S.A. \& Tyrell, M.F. A new theory of the termination of action of the muscle relaxants. Proc. R. Soc. Med. 63: 692 (1970).

9. WAUD, B.E. Serum d-tubocurarine concentration and twitch height. Anesthesiology 43: 381 (1975).

10. Foldes, F.F., de VOChT, M., \& vaN dE Pol, F. Lack of relationship between the pharmacokinetics of the in vitro reversal of neuromuscular blocking agents and the duration of their in vivo effect. Abstracts of Scientific Papers. American Society of Anesthesiologists Annual Meeting, 1976.

11. Gibaldi, M., Levy, G., \& Hayton, W.L. Tubocurarine and renal failure. Brit. J. Anaesth. 44: $163(1972)$. 
12. Millen, R.D., Matteo, R.S., Sohn, Y.J., \& Eger, E.I. Renal failure and plasma concentrations of d-tubocurarine and its neuromuscular blockade in man. Abstracts of Scientific Papers. American Society of Anesthesiologists Annual Meeting, 1976.

13. MCINTYRE, J.W.R. \& GAN, E.A. Initial experience during the clinical use of pancuronium bromide. Anesth. Analg. 50: 813 (1971).

14. Chunchill-Davidson, H.C., Way, W.L., \& DE Jong, R.H. The muscle relaxants and renal excretion. Anesthesiology 28: 540 (1967).

15. Popescu, D.T. Muscle relaxants in anephric patients. Anesthesia \& Pharmaceutics. Edited by J. Spierdijh \& S.A. Feldman, Baltimore, Williams \& Wilkins Company, p. 74 (1972). 